ADDIN, Volume 10, Number 2, August 2016

\title{
THE ROLE OF PONDOK PESANTREN IN ENCOUNTERING ASEAN ECONOMIC COMMUNITY (AEC)
}

\section{Ulin Nuha}

Istanbul University, Turkey

baarakallab23@gmail.com

\begin{abstract}
ASEAN Economic Community (AEC) with characteristics of the economy and labour liberalization can be a blessing for Indonesian people when they are ready to deal with it, but it can also be disastrous if they do not prepare it. This requires the synergy of government and all elements of Indonesian society in facing the ASEAN Economic Community (AEC). Boarding school in the context of history has become an institution that is bighly effective not only in the printing community deeply in the science of religion, but also in terms of the economy certainly cannot remain silent in facing the ASE AN Economic Community (AEC).
\end{abstract}

Keywords: Boarding School, ASEAN Economic Community (AEC).

\section{Abstrak}

ASEAN Economic Community (AEC) dengan cirinya liberalisasi perekonomian dan liberalisasi tenaga kerja bisa menjadi berkah bagi bangsa Indonesia bila siap menghadapinya, namun bisa juga menjadi 
malapetaka bila tidak siap menghadapinya. Untuk itu, diperlukan sinergi dari pemerintah dan selurub elemen masyarakat Indonesia dalam menghadapi ASEAN Economic Community (AEC). Pondok pesantren yang dalam konteks sejarah telah menjadi lembaga yang sangat efektif tidak hanya dalam pencetakan masyarakat yang mendalam dalam ilmu agama, tetapi juga dalam bal perekonomian tentu saja tidak bisa tinggal diam dalam menghadapi ASEAN Economic Community (AEC).

Kata Kunci: Pondok Pesantren, ASEAN Economic Community (AEC).

\section{A. Introduction}

ASEAN Economic Community (AEC) is the realisation of the end goal of economic integration as espoused in the Vision 2020, which is based on a convergence of interests of ASEAN Member Countries to deepen and broaden economic integration through existing and new initiatives with clear timelines. In establishing the AEC, ASEAN shall act in accordance to the principles of an open, outwardlooking, inclusive, and market-driven economy consistent with multilateral rules as well as adherence to rules-based systems for effective compliance and implementation of economic commitments ${ }^{1}$.

Minister of State for Trade, Rachmat Gobel stated that ASEAN Free Trade that is parallel with ASEAN Economic Community (AEC) is a threat for ASEAN community. However, it must be interpreted in a positive think so we can exploit this threat into an opportunity ${ }^{2}$.

For Indonesia, with its the largest total population, area, geographic location and value of GDP (Gross Domestic

${ }^{1}$ Association of Southeast Asian Nation, ASEAN Economic Community Blueprint, Retrieved via http://asean.org/wp-content/uploads/archive/5187-10. pdf. on 8th August 2016.

${ }^{2}$ Warta Ekspor, Peluang dan Tantangan Indonesia Pasar Bebas ASEAN, January 2015, p. 6. 
Product) in ASEAN should be an asset in order to become a major player in AEC (ASEAN Economic Community) in 2015. AEC (ASEAN Economic Community) will be a good opportunity for Indonesia because trade barriers will tend to diminish even will disappear. It will have an impact on increasing exports, which further will increasing GDP.

In order to optimize all of that advantages, it is required a synergy from all of elements of the nation. Starting from the government until all elements of Indonesian society. Pondok pesantren which becomes an effective institution not only in religious community building, but also in economic resilience in the historical context certainly can't stay silent in encountering ASEAN Economic Community (AEC).

This article will explain what kind of the role that could be taken by pondok pesantren in encountering ASEAN Economic Community (AEC).

\section{B.Discussion}

\section{AEC: the Opportunity for Indonesia that should be} Taken

The emergence of the ASEAN Economic Community (AEC) can't be separated from the declaration of the ASEAN Free Trade Area (AFTA), which launched on 1th January, 1993. The concept of AFTA itself is an embodiment of a Free Trade Area (FTA), which was promoted by the World Trade Organization (WTO). So that all countries that are members of the WTO, including ASEAN countries automatically have to be willing to open markets for other countries and accept the consequences of free trade ${ }^{3}$.

${ }^{3}$ Gilpin and Gilpin, 2000 in the Peningkatan Daya Saing Industri Indonesia Guna menghadapi Asean-China Free Trade Area Agreement (ACFTA) dalam Rangka Memperkokoh Ketahanan Nasional, Indonesian National Defense Journal of Studies 14th December 2012 edition. 
All of the concept in AFTA really aims to improve the competitiveness of ASEAN products in the world markets and create a possible extent market to stimulate an increase in FDI (Foreign Direct Investment) in Southeast Asia, which means that all of the goods or products which produced by ASEAN can be traded in member countries with or without tariff rates $^{4}$. Recent developments related to AFTA is an agreement to abolish all customs duties for the import of goods in 2010 for Brunei Darussalam, Indonesia, Malaysia, Philippines, Singapore and Thailand, and for Cambodia, Laos, Myanmar and Vietnam in $2015^{5}$.

One of the purposes of establishing the ASEAN Economic Community (AEC) is to support ASEAN countries economy, but the implementation of this purpose is being a difficult choice for some countries which do not have a strong economy. The Countries that have weak economic experience will be in difficult position because efficiency of production, capital efficiency of production and the total of competitive products in each country are still weak so it precisely will make that countries fall in the damage.

As one of the ASEAN member countries that have a broad market, of course, Indonesia position is very strategic for manufacturers because the proportion of Indonesian population is much higher than other ASEAN member countries so Indonesia will be manufacturers target in marketing goods and services. AEC is very important for Indonesia because it will determine the future of Indonesia, whether Indonesia is able to play an active role as an actor or as a spectator. With all Indonesia abundance, both human resources and natural resources, this moment is very important for the progress

${ }^{4}$ Cuyvers Ludo and Wisran Pupphavesa. 1996, From ASEAN to AFTA .CAS Discussion paper No. 6.

${ }^{5}$ Indonesian Ministry of Finance, General Explanation Rates, Retrieved via http://www.tarif.depkeu.go.id/Others/?hi=AFTA on 6 ${ }^{\text {th }}$ August 2016. 
of Indonesia. Despite there are many challenges that must be faced by Indonesia, nonetheless Indonesia still has a lot of opportunities if Indonesia really an actor in the AEC. If the government and all elements of Indonesian society fight together in ASEAN free market competition, then Indonesia will be able to become the real Asian Tigers. Therefore Indonesia will able to take maximum benefit in the ASEAN Economic Community (AEC).

One element of Indonesian society that cannot be denied its role is pondok pesantren. Since the colonial era until this construction time, pondok pesantren is always present its selves as the defenders of the nation's elements which always gives positive impacts in all areas.

\section{Pondok Pesantren and its Role in the Society}

According to its origin, the word "pesantren" is derived from the word "santri" which gets prefix "pe" and suffix "an" which shows the place, it means thtat "pesantren" is a place of santri. Sometimes, "pesantren" considered as a combination of the word "santri" (good human) with the syllable "tra" (helpful) so the word "pesantren" means an educational institutions for good and helpful human".

As for the word "santri" is is derived from the word "sastri" (Sanskrit), its means they who able to read and further connoted to literary class for Javanese people due to their religion knowledge from Arabic books. Then it is assumed that "santri" means a person who knows about the religion through Arabic books and or at least "santri" is a person who able to read the Quran, thus bringing him to more seriously in viewing religion. Also the word "santri" comes from Javanese "cantrik" means a person who always follows his teacher where teachers

${ }^{6}$ Abdullah Syukri Zarkasyi, Langkah Pengembangan Pesantren, dalam Abdul Munir Mulkhan, (ed) Rekontruksi Pendidikan dan Tradisi Pesantren Religiusitas Iptek (Yogyakarta: Pustaka Pelajar, 1998), p. 106. 
went to live (the term of pewayangan) with the aim to learn from him about certain expertise ${ }^{7}$.

The word "pesantren", usually added with the word "pondok", then the term "pondok pesantren". Linguistically, the word "pondok" is derived from Arabic word "funduq" which means bedroom, guesthouse, simple hotel, or connotes dwellings made from bamboo ${ }^{8}$.

Thus, the term "pondok pesantren" simply can be defined as a place or the complex of santri (students) to learn or recite the religious sciences from kiai or teacher of the Quran. Exhaustively, definition of pondok pesantren was explained by the experts. Below is the definition of "pondok pesantren" that was explained by the experts:

a. Zamaksary Dhofier defines that pondok pesantren is an Islamic traditional education institutions to learn, understand, appreciate and practice the teachings of Islam by stressing the importance of religious morals to guide daily behaviour?

b. Nasir Ridlwan defines that pondok pesantren is a religious institution that provides education and teaching as well as develop and disseminate knowledge of Islam $^{10}$.

c. Indonesian Department of Religion Writer team defines that pondok pesantren is the education and teaching of Islam in which there is interaction between the kiai (ulama) and ustdaz as a teacher and the students (santri) with took place at the mosque or in the yard dormitory (pondok) to examine and discuss religious textbooks of ulama of

${ }^{7}$ Nurcholis Madjid, Bilik-Bilik Pesantren Sebuah Potret Perjalanan, (Jakarta: Paramadina, 1997), p. 19-20.

${ }^{8}$ Abdullah Syukri Zarkasyi, “Langkah Pengembangan Pesantren”, ., p. 105-106.

${ }^{9}$ Zamakhsyari Dhofier, Tradisi Pesantren Studi tentang Pandangan Hidup Kyai, (Jakarta: LP3S, 1983), p.18.

${ }^{10}$ Ridlwan Nasir, Mencari Tipologi Format Pendidikan Ideal, Pondok Pesantren di Tengah Arus Perubaban (Yogyakarta: Pustaka Pelajar, 2005), p.80. 
the past. Thus, the most important element for pondok pesantren are kiai (ulama), santri (students), mosque, place of residence (pondok) and books (kitab kuning) ${ }^{11}$.

d. Rabithah Ma'ahid Islamiyah (RMI) defines that pondok pesantren is a tafaqquh fi al-din institutions which carries forward the message of Mohammad SAW while preserves the doctrine Ablu al-Sunnah wa al-Jama'ah 'ala al-Mazabib Thoriqob al-'Arba 'Ah.

e. Mastuhu defines that defines that pondok pesantren is an Islamic traditional education institutions to learn, understand, appreciate and practice the teachings of Islam (tafaqquh fi al-din) by emphasizing the importance of religion as a moral social daily guideline ${ }^{12}$.

f. M. Arifin defines pondok pesantren as an Islamic educational institution that is growing and recognized by the surrounding community, with the dormitory system (campus) where receive religious education through lectures or madrasah system that is fully under the sovereignty of leadership one or several kiai (ulama) with charismatic and independent in all thing characteristics ${ }^{13}$.

At first, pondok pesantren was a center of Islamic educational and Islamic religious spreading. However, in its growth, pondok pesantren become not only Islamic educational which only accelerate the vertical mobility (with stuffing of religious materials), but also horizontal mobility (social consciousness). Nowadays, pondok pesantren become society based curriculum. Thus, pondok pesantren become the social

${ }^{11}$ Indonesian Department of Religion Writer team, Pondok Pesantren dan Madrasah Diniyah Pertumbuhan dan Perkembangan (Jakarta: Religious Affairs Directorate General of Islamic Religious Institutions, 2003), p. 3.

${ }^{12}$ Mastuhu, Dinamika Sistem Pendidikan Pesantren, (Jakarta: INIS, 1994), p. 6.

${ }^{13}$ M. Arifin, Kapita Selekta Pendidikan Islam dan Umum (Jakarta: Bumi Aksara, 1991), p. 240 
institutions that continue to respond messy issues surrounding its society ${ }^{14}$.

In the context of history, pondok pesantren in its capacity as a center of the society struggle become an institution that is very effective in the fight against the invaders; then in the 1980, through the Center for Pesantren and Society Development (P3M), pondok pesantren acquire its additional function, namely as a center for society empowerment. Therefore, so many pondok pesantren that is made as a test for people's empowerment. For example Pesantren Darul Falah Bogor, Pesantren Pabelan Magelang, Pesantren Kajen Pati, Pesantren Langitan Tuban, Pesantren An-Nuqayah Madura and others that serve as centers of society empowerment. The bustle of society empowerment then be outstanding in pondok pesantren. Further, in 2000s, pondok pesantren acquire its additional function again as central of social economy development. Then came pondok pesantren with his trademark develop cooperatives, such as pondok pesantren Sidogiri. This condition marked that truly, pondok pesantren is not devoid of innovation. And it also indicates that pondok pesantren has very high response to changing times. So, in fact pesantren is a social and educational institution, and also economic society empowerment ${ }^{15}$.

With its characteristics, certainly pondok pesantren is ready to play its role in helping Indonesia to encounter ASEAN Economic Community (AEC). 2006), p. 1.

${ }^{14}$ HS Mastuki, El-Sha, M. Ishom, Intelektualisme Pesantren (Jakarta: Diva Pustaka,

${ }^{15}$ H.M. Hamdan Rasyid, Peran Pesantren Dalam Pengembangan Ekonomi Islam, Retrieved via http://syariah.feb.unair.ac.id/wp-content/uploads/Peran-Pesantren-dalamPengembangan-Ekonomi-Islam.pdf on $6^{\text {th }}$ August 2016. 


\section{The Role of Pondok Pesantren in Encountering ASEAN Economic Community (AEC)}

There are at least three roles that could be played by pondok pesantren in encountering ASEAN Economic Community. First, the role of scientific development and socialization of the economy based on the religious sciences to the public. This is because pondok pesantren is an institution that teaches religious sciences, including figh muamalah explaining about economy beside on figh. Pondok pesantren graduates are potentially as a mouthpiece for socialization of economy based on religious sciences in society, because they are role models and their voice more audible than non pesantren graduates. Economies based on religious knowledge will be greatly needed by people in encountering the ASEAN Economic Community, where economic liberalization would enable a person to perform a variety of ways in order to compete with other people both from their country and from other countries.

Second is the role of realizing the real practice laboratories in economic activity. This role is also very strategic, because public sees pondok pesantren as examples and role models in their daily activities. If pondok pesantren develops its economic potential, it will be followed by the public. In addition, as has been practiced by some pondok pesantren, the pondok pesantren with its santri (students) living in pondok pesantren 24 hours, can easily organize economic trainings to all its santri (students) and all community around its environment. By carrying out this role, students who have graduated from pondok pesantren, besides knowing religious knowledge, they will also be ready to compete with the public both from their country and from other countries in economy field.

Third, pondok pesantren could serve as an institutional production by moving santri (students) and people in its 
environment together. Pondok pesantren with the total of its santri (students) can put a lot of its santri (students) who have been trained with real practice laboratories in economic activity. Santri (students) who have been empowered, on his return from pondok pesantren will have economic sciences sufficient. Therefore, they can compete in the ASEAN Economic Community. In addition, the boarding school could also mobilize the community around pesantren to be placed in institutions such production, and thus, pondok pesantren can empower communities, so that people would not be confused to find employment. As we know, the main feature of the ASEAN Economic Community is liberalization of labor, where the people of the country will compete with other workers not only with workers who are in their country but also with workers from other countries. By taking on this role, pondok pesantren will help people in its community and certainly pondok pesantren also will help government in encountering the ASEAN Economic Community (AEC).

In order to be able to implement all the roles, pondok pesantren must innovate in various fields. If it only relies on traditional ways, the development will tend to stagnate. Therefore, there is a needed full innovation effort from pondok pesantren in order to be able to play in its role in the ASEAN Economic Community (AEC) which cannot be avoided anymore. As has been pointed out, the authors believe, the boarding school will be best able to contribute to society and the nation in facing the ASEAN Economic Community (AEC).

\section{C.Conclusion}

By looking at pondok pesantren's contribution in the real conditions from year to year, the authors conclude that there are three roles that could be played by pondok pesantren in encountering the ASEAN Economic Community (AEC). 
Those three roles are the role of scientific development and socialization of the economy based on the religious sciences to the public, realizing the real practice laboratories in economic activity and Pondok pesantren could serve as an institutional production by moving santri (students) and people in its environment together. In order to be able to implement all of those roles, pondok pesantren must innovate in various fields. If we only rely on traditional ways, the development will tend to stagnate. Therefore, there is a need of full innovation efforts from pondok pesantren in order to be able to play in its role in the ASEAN Economic Community (AEC) which can't be avoided anymore. And as has been pointed out, the authors believe, the boarding school will be best able to contribute to society and the nation in facing the ASEAN Economic Community (AEC). 


\section{REFERENCES}

Arifin, M, Kapita Selekta Pendidikan Islam dan Umum, Jakarta: Bumi Aksara, 1991.

Association of Southeast Asian Nation, ASEAN Economic Community Blueprint. Retrieved from: http://asean.org/ wp-content/uploads/archive/5187-10.pdf.

Dhofier, Zamakhsyari, Tradisi Pesantren Studi tentang Pandangan Hidup Kyai, Jakarta, LP3S, 1983.

Gilpin and Gilpin, Peningkatan Daya Saing Industri Indonesia Guna menghadapi Asean-China Free Trade Area Agreement (ACFTA) dalam Rangka Memperkokob Ketahanan Nasional. Indonesian National Defense Journal of Studies, 14th December 2012.

HS, Mastuki, El-Sha, M. Ishom, Intelektualisme Pesantren, Jakarta: Diva Pustaka, 2006.

Indonesian Department of Religion Writer team, Pondok Pesantren dan Madrasah Diniyah Pertumbuban dan Perkembangan, Jakarta: Religious Affairs Directorate General of Islamic Religious Institutions, 2003.

Indonesian Ministry of Finance, General Explanation Rates, http://www.tarif.depkeu.go.id/Others/?hi=AFTA. 6 $^{\text {th }}$ August 2016.

Ludo, Cuyvers, Pupphaves, Wisran, From ASEAN to AFTA .CAS Discussion paper No. 6, 1996.

Madjid, Nurcholis, Bilik-Bilik Pesantren Sebuab Potret Perjalanan, Jakarta: Paramadina, 1997.

Mastuhu, Dinamika Sistem Pendidikan Pesantren, Jakarta: INIS, 1994. 
Nasir, Ridlwan, Mencari Tipologi Format Pendidikan Ideal, Pondok Pesantren di Tengah Arus Perubahan, Yogyakarta: Pustaka pelajar, 2005.

Rasyid, Hamdan, H.M, Peran Pesantren Dalam Pengembangan Ekonomi Islam, Retrieved via http://syariah.feb.unair. ac.id/wp-content/uploads/Peran-Pesantren-dalamPengembangan-Ekonomi-Islam.pdf, 2016.

Warta Ekspor, Peluang dan Tantangan Indonesia Pasar Bebas ASEAN, 2015.

Zarkasyi, Syukri, Abdullah. Langkah Pengembangan Pesantren, dalam Abdul Munir Mulkhan, (ed) Rekontruksi Pendidikan dan Tradisi Pesantren Religiusitas Iptek, Yogyakarta: Pustaka Pelajar, 1998 
Ulin Nuha

Halaman ini tidak sengaja untuk dikosongkan 